ment of malignancy. In my view patients benefit more from a shorter period of relative comfort than prolonged misery through drastic treatment, even though the latter may lead more rapidly to eventual cures for other people.

Recently I witnessed on television a rather sordid dispute between medical people on human experimentation in hospital. I doubt that this will help when I have to persuade a nervous patient that hospital admission is essential. If asked by a patient, "Will they experiment on me ?" what do I answer? So much of medical practice is experimental that we must be trusted not to carry this too far. We cannot believe in God and act like one at the same time.

Statistics, too, seem to be in the ascendancy, mainly, I assume, because of the convenience of interpreting them in accordance with the trend of the times. For instance, article upon article exhorts me to encourage smokers to desist, but are there any statistics to show what will happen when the heavy smokers, who are orally dependent, abstain? Will their demise be any further off, suffering from obesity and cardiac debility secondary to increased intake of confectionery? What percentage will degenerate under the influence of alcohol or drugs, and how many innocents will they slaughter on the roads? Indeed, will their increased sexual prowess be a problem of import ? These are only a few of many questions that might be considered. Personally, I shall know some of the answers soon myself, having just given up smoking, mainly for financial reasons.

Finally, stress. The percentage of patients who require a doctor's help through being unable to stand the strain of modern living increases yearly. Many of the patients are of sufficient calibre to give one the impression that they have been subjected to more stress than the majority of persons could adequately have coped with, and do not come under the heading of inadequate personalities. Thus there is a great need for research by medical and other authorities into stress and the avoidance of excessive strain. This would indeed remove so many problems from, and increase greatly the standard of, medicine in general practice.-I am, etc.,

$$
\begin{aligned}
& \text { GrAHAM KNIGHT-WEBB. } \\
& \text { Minchinhampton, } \\
& \text { Gloucestershire. }
\end{aligned}
$$

\section{Pulmonary Oedema}

SIR,-The recent articles concerned with pulmonary oedema (July 13, pp. 80 and 83 ) give a further stimulus to those of us interested in the complications of intracranial and spinal injuries. The review by Dr. P. Richards (p. 83) is very valuable, but a study of pulmonary oedema of neurogenic origin is probably more fruitful if the factors of increased intracranial pressure and operative trauma are excluded. Blood products in the cerebral :entricles are a potent source of pulmonary oedema. ${ }^{1}$
The vast amount of experimental physiology on the central autonomic system points strongly to the presence of numerous receptor centres, perhaps of almost pin-point size, and located chiefly in the hypothalamus. While it is agreed that conclusions drawn from animal experiments must be guarded in their application to the human, nevertheless such experiments provide a basis for ideas which can be applied to the study of clinical states. (With due respect to Dr. Richards, it is still controversial that bilateral division of the vagus of itself can produce pulmonary oedema except in the guinea-pig.)

Macroscopic study is not able to detect trauma to which nerve cells and their neurones may be subjected. It seems bevond doubt that gross damage to nerve cells and fibres may even be missed by the microscope. ${ }^{2-4}$ Moreover, a surprising amount of recovery may follow traumatic lesions in the central nervous system. Therefore it can be inferred that physiological lesions occur which are reversible.

There is abundant evidence in favour of the general concept of central receptor centres concerned with autonomic function. It is essential to appreciate that perverted activity of the autonomic system may result from damage to the afferent and efferent tracts associated with these centres, as well as trauma to the cells of the centres themselves. Hence it is unlikely that a central solitary and anatomically precise location will be found to explain every particular complication occurring in the periphery.

From a study of head and high spinal injuries over many years it was concluded $^{5}$ that so-called hypostatic pneumonia was in essence a pulmonary oedema of neurogenic origin. It was further concluded that the damage to the central areas of autonomic function resulted in a perverted release of adrenergic activity in the periphery. Destruction of the peripheral sympathetic system does not precipitate pulmonary oedema.

In gross damage to the brain stem there is frequently observed a triad of complications consisting of pulmonary oedema, acute hypertension, and hyperthermia. Arnott ${ }^{6}$ suggested that the pulmonary oedema of head injuries was due to the acute rise in systemic vasoconstriction, and indeed the so-called adrenaline oedema may add support to that view. Nevertheless, as pointed out in a letter to the B.M.J., ${ }^{7}$ acute hypertension is not invariable in pulmonary oedema. an observation confirmed by Dr. Richards Certainly it is absent in the pulmonary oedema associated with high spinal injuries. There seems little doubt that neurogenic pulmonary oedema results from some peculiar disturbance of haemodynamics and hence the apt term, neurohaemodynamic. coined by Sarnoff. If this disturbance of haemodynamics is determined by some localized release of adrenergic function in the periphery, then inhibition of such adrenergic function should - cure neurogenic pulmonary oedema. Success has been claimed by Fontaine and Courtine ${ }^{\circ}$ by the injection of local anaesthetic into the upper dorsal sympathetic ganglia. An injection of ergotamine tartrate produced a dramatic effect in a severe pulmonary oedema associated with a high spinal transection. ${ }^{10}$

Experimentally the development of pulmonary oedema has been judged on the alteration of the heart-lung weight ratio. It is desirable to distinguish oedema of the lung tissues from the condition of oedema fluid in the air passages. In some work, unpublished as yet, I have had the temerity to coin the word pneumoedema for this latter state for the purpose of clarity in argument. There seems little doubt that these oedematous states can readily predispose to pneumonic changes. Such terminal pneumonia, described under several terms by pathologists, has no doubt tended to mask the true pathological changes. Moon ${ }^{11}$ has reviewed these terminal states. Dr. Richards comments on the variable site of these changes, though they are most commonly basal. Certainly posture plays a leading part. The sheep on its back will quickly succumb with acute pulmonary oedema, a fact well known to country folk. The bucolic wisdom of going immediately to the sheep's assistance is well founded. Even so the distribution of blood flow and ventilation in the lungs is a study in itself, and the recent edition of the British Medical Bulletin on "Respiratory Physiology" is of great value to those interested in the problems of pulmonary oedema.-I am, etc.

\section{Wembley Hospital, \\ Wembley, Middlesex. \\ J. S. Callcutt.}

\section{REFERENCES}

Noordenbos, W., Folia psychiat. neerl., 1954. 57 th year No. $4 / 5,405$

Greenfield, J. G., Proc. roy. Soc. Med., 1938,

32, 43.

Lhermitte, J., Folia psychiat. neerl., 1950 (Brouwer Mem. Vol.).

- Strich Sabina, J., Lancet, 1961, 2, 443

5 Callcutt, J. S., Med. Wld (Lond.), 1943, 58, 279.

- Arnott, W. M., Brit. med. J., 1955, 2. 342

Callcutt, J. S., ibid., 1955, 2, 735

Sarnoff, S. J., J. Physiol., 1952, 117, 38P

Fontaine, R., and Courtine, G., Presse méd. 1940, 48, 711 .

10 Callcutt, J. S., Med. Wld (Lond.), 1945, 62.

1 Moon, V. H., Arch. Path., 1938, 26, 132.

\section{Discharge from Mental Hospitals}

SiR,-OOn four occasions so far this year I have been called by the police to attend patients who have recently been in a mental hospital. Three of these patients, a man and two women, were picked up wandering about in a confused state and required immediate readmission to a mental hospital. They had previously been in hospitals outside the Oxford area.

The fourth patient, an elderly man, was found dead on the floor of his squalid dwelling. He had been dead for about two months. Necropsy did not reveal the cause of death. He had been discharged from a mental hospital a few days before last being seen alive. 